\section{PERAN NOTARIS DALAM PROSES PERADILAN PIDANA ${ }^{1}$ \\ Oleh : Pricilia Yuliana Kambey ${ }^{2}$}

\section{ABSTRAK}

Tujuan dilakukannya penelitian ini adalah untuk mengetahui bagaimanakah keberadaan Notaris sebagai Pejabat Umum dalam memberikan kesaksian terhadap suatu perkara menyangkut akta yang dibuatnya dalam proses peradilan pidana dan bagaimanakah peran notaris dalam memberikan keterangan untuk membantu proses peradilan pidana dikaitkan dengan rahasia jabatannya. Dengan menggunakan metode penelitian hukum normatif disimpulkan bahwa : 1 . Dalam hal memberikan kesaksian, seorang notaris tidak dapat mengungkapkan akta yang dibuatnya balk sebagian maupun keseluruhannya kepada pihak lain, hal ini sesuai dengan Pasal 54 Undang-Undang Jabatan Notaris karena sebagai seorang kepercayaan, notaris berkewajiban untuk merahasiakan semua hal yang diberitahukan kepadanya dalam jabatannya sebagai notaris, sekalipun ada sebagian yang tidak dicantumkan dalam akta, dan telah dianggap mewakili diri notaris dalam suatu persidangan sehingga akta yang, dibuat oleh atau di hadapan notaris merupakan suatu alat bukti yang mempunyai kekuatan pembuktian yang sempurna. 2. Seorang notaris harus mendapatkan persetujuan terlebih dahulu dari Majelis Pengawas Daerah dan harus jelas kedudukannya dalam suatu perkara sebagai saksi atau tersangka terhadap akta yang dibuatnya, serta harus jelas keterangan apa yang diperlukan oleh penyidik, penuntut umum, maupun hakim, namun notaris dibatasi dengan rahasia jabatan sebagaimana yang tercantum dalam sumpah jabatan notaris dalam Pasal 4 dan kewajiban notaris dalam Pasal 16

\footnotetext{
${ }^{1}$ Artikel Skripsi

${ }^{2}$ NIM 090711047
}

ayat (1) huruf e Undang-Undang Jabatan Notaris. Dalam penjelasan Pasal tersebut dikatakan bahwa kewajiban untuk merahasiakan segala sesuatu yang berhubungan dengan akta dan surat-surat lainnya adalah untuk melindungi kepentingan semua pihak yang terkait dengan akta tersebut. Notaris tidak hanya berhak untuk bicara, akantetapi mempunyai kewajiban untuk tidak bicara. Kewajiban tersebut mengesampingkan kewajiban umum yang tercantum dalam, Pasal 1909 ayat (1) KUHPerdata karena dalam profesi notaris dikenal adanya istilah mengenai hak ingkar yaitu merupakan konsekuensi dari adanya kewajiban merahasiakan sesuatu yang diketahuinya. Kata kunci: Notaris

\section{A. PENDAHULUAN}

Berdasarkan ketentuan yang diatur dalam Pasal 60 ayat (1) huruf $a$ dan $b$ Undang-Undang Jabatan Notaris, menyatakan bahwa : Untuk kepentingan proses peradilan, Penyidik, Penuntut Umum, atau Hakim dengan persetujuan Majelis Pengawas Daerah berwenang untuk

a. Mengambil fokopi Minuta Akta dan/atau surat-surat yang diletakan pada Minuta Akta dan/atau Protokol Notaris dalam penyimpanan notaris;

b. Memanggil notaris untuk hadir dalam pemeriksaan yang berkaitan dengan akta yang dibuatnya atau Protokol Notaris yang berada dalam penyimpanan notaris.

Dengan adanya ketentuan tersebut di atas, untuk kepentingan penyelidikan, harus mendapat persetujuan Majelis Pengawas Daerah. Pembentukan Majelis Pengawas, termasuk tata caranya, bagaimana pemeriksaannya kemudian bagaimana proseduralnya diatur dalam Peraturan Menteri. Dalam menindak lanjuti laporan masyarakat yang merasa dirugikan atas pembuatan akta, kemudian mengajukan laporan kepada Majelis 
Pengawas Daerah, kalau ada pelanggaranpelanggaran yang terjadi maka telah diatur sanksi-sanksinya, berupa teguran lisan, tertulis, pemberhentian sementara ataupun permanen. Hal tersebut menunjukan adanya kerahasiaan dan bahwa tidak dengan mudah untuk mengambil fotokopi Minuta Akta dan/atau surat-surat yang diletakan pada Minuta Akta atau Protokol Notaris dalam penyimpanan notaris $d n$ memanggil notaris untuk hadir dalam pemeiksaan yang berkaitan dengan akta yang dibuatnya atau Protokol Notaris yang berada dalam penyimpanan notaris.

\section{B. PERUMUSAN MASALAH}

1. Bagaimanakah keberadaan Notaris sebagai Pejabat Umum dalam memberikan kesaksian terhadap suatu perkara menyangkut akta yang dibuatnya dalam proses peradilan pidana?

2. Bagaimanakah peran notaris dalam memberikan keterangan untuk membantu proses peradilan pidana dikaitkan dengan rahasia jabatannya ?

\section{PEMBAHASAN}

1. Keberadaan Notaris Sebagai Pejabat Umum Dalam Memberikan Kesaksian Terhadap Suatu Perkara Menyangkut Akta Yang Dibuatnya

Dalam menjalankan tugasnya, notaris memiliki sejumlah kewenangan yang dilakukannya. Definisi kewenangan adalah hak dan kekuasaan yang dipunyai untuk melakukan sesuatu. ${ }^{3}$ Terkait dengan kewenangan yang dimiliki notaris, maka notaris merupakan pejabat umum yang berwenang membuat akta otentik. Hal ini berdasarkan ketentuan Pasal 1868 KUHPerdata yang menyatakan bahwa : Suatu akta otentik ialah suatu akta yang di dalam bentuk yang ditentukan oleh Undang-Undang, dibuat oleh atau di

\footnotetext{
3 Kamus Besar Bahasa Indonesia, Balai Putaka, Jakarta, 1994, hal 1128
}

hadapan pegawai-pegawai umum yang berkuasa untuk itu di tempat di mana akta dibuatnya. Sebagai pelaksanaan dan penjabaran Pasal 1868 KUHPerdata tersebut, maka terlebih dahulu harus tentukan yang di maksud dengan pejabat umum tersebut. Berdasarkan Pasal 1 Undang-Undang Jabatan Notaris, maka pejabat tersebut adalah notaris. Kewenangan Notaris berdasarkan ketentuan Pasal 15 ayat (1) UndangUndang Jabatan Notaris yaitu: Notaris berwenang membuat akta otentik mengenai semua perbuatan, perjanjian, dan ketetapan yang diharuskan oleh peraturan perundang-undangan dan/atau yang dikehendaki oleh yang berkepentingan untuk dinyatakan dalam akta otentik, menjamin kepastian tanggal pembuatan akta, menyimpan akta, memberikan grosse, salinan dan kutipan akta,semuanya itu sepanjang pembuatan akta-akta itu tidak juga ditugaskan atau dikecualikan kepada pejabat lain atau orang lain yang ditetapkan oleh Undang-Undang.

Mengenai kewenangan notaris sebagai pejabat umum, maka terdapat unsur unsur sebagai berikut :

a) "Pejabat Umum", bukan berarti notaris itu merupakan pegawai negeri yang dimaksud dalam Undang-Undang No. 8 Tahun 1974 tentang Pokok-pokok Kepegawaian, melainkan jabatan yang dimaksud dalam Pasal 1868 KUHPerdata. ${ }^{4}$ Notaris meskipun diangkat dan diberhentikan oleh pemerintah tapi tidak menerima gaji, pensiun dari pernerintah. ${ }^{5}$ Jabatan Notaris bukan suatu jabatan yang di gaji, notaris tidak menerima gaji dari pemerintah, melainkan mendapatkan

\footnotetext{
4 Komar Andasasmita,Notaris Selayang Pandang, Bandung, Alumni, 1983, hal. 2.

5 Habib Adjie., Hukum Notaris Indonesia, (Tafsir Tematik Terhadap UU No 30 Tahun 2004 Tentang Jabatan Notaris), PT. Refika aditama, Surabaya, 2008 hal. 16.
} 
honorarium dari mereka yang meminta jasa seorang notaris.

b) "Akta Otentik", menurut Pasal 1868 KUHPerdata yang dimaksud ialah suatu akta yang di dalam bentuk menurut ketentuan Undang-Undang dibuat oleh atau di hadapan pejabat umum yang berwenang untuk itu di tempat di mana akta itu dibuat.

c) "Semua perbuatan perjanjian dan penetapan yang diharuskan oleh suatu peraturan umum atau yang dikehendaki oleh yang berkepentingan", dapat dirnaklurni bahwa akta-akta yang dibuat oleh atau di hadapan notaris itu terbatas pads akta-akta yangmenyangkut hokum perdata dan apa yang dikehendaki oleh yang berkepentingan itu dan berdasarkan Undang-Undang (peraturan hukum).

d) "Menjamin kepastian tanggalnya", hendaknya di artikan tanggal dibuat dan ditandatanganinya akta yang bersangkutan menurut kenyataannya.

e) "Menyimpan aktanya", yang mengharuskan para notaris untuk menyimpan Minuta Akta, Repertorium, Buku Daftar Akta di bawah tangan, Klipper, Buku Daftar Protes, Buku Daftar Wasiat, Buku Daftar lainnya yang harus di simpan oleh notaris. Dan harus menyimpannya dengan cermat atau seksama di tempat yang patut dan aman.

f) "Grosse Akta", mempunyai kekuatan eksekutorial yang sama seperti yangdiberikan kepada putusan hakim (vonis) yang bagian atasnya bertuliskan "DEMIKEADILAN BERDASARKAN KETUHANAN YANG MAHA ESA".

Wewenang yang diberikan kepada notaris pada prinsipnya merupakan wewenang yang bersifat umum. Wewenang yang bersifat umum artinya bahwa wewenang ini meliputi pembuatan segala jenis akta, kecuali yang dikecualikan tidak dibuat oleh notaris. Perkataan ini jugs mengandung arti bahwa pejabatpejabat lain, selain notaris hanya mempunyai kewenangan akta tertentu saja dan harus berdasarkan peraturan perundangundangan yang mengaturnya. Notaris dalam melaksanakan tugas sebagai pejabat umum harus bersikap tidak memihak, sesuai dengan isi sumpah jabatannya, yang menentukan bahwa notaris akan menjalankan tugas jabatannya dengan amanah, jujur, seksama, mandiri, dan tidak berpihak.

Kewajiban Notaris selaku Pejabat Umum.

Inti dari tugas Notaris sebagai pejabat umum ialah merekam secara tertulis dan otentik hubungan-hubungan hukum antara para pihak, yang secara mufakat meminta bantuan jasa-jasa Notaris. ${ }^{6}$ Sedapat mungkin notaris harus berupaya mengetahui bahwa identitas dan keterangan dari para pihak adalah yang sebenarnya. Notaris dapat memperoleh keterangan-keterangan tersebut dari orang-orang yang dikenalnya dan dipercayainya atau dapat melihat bukti identitas dari para pihak. Akan tetapi apabila ternyata segala keterangan yang diberikan oleh para pihak tersebut adalah tidak benar, maka semuanya itu bukanlah tanggung jawab dari notaris, karena notaris hanya bertanggung jaawab atas kebenaran formil yang telah diberikan olehpara pihak. Berdasarkan hal tersebut, maka pertanggung jawaban notaris terhadapakta yang dibuatnya harus didukung oleh suatu itikad moral yang dapat dipertanggung jawabkan. Akta otentik yang dibuat oleh Notaris mengandung arti,bahwa akta otentik merupakan bukti yang sempurna tentang apa yang dibuat didalamnya.

Dalam persidangan hakim sangat memerlukan adanya alas-alas bukti untuk dapat mencapai suatu putusan dan penyelesaian perkara secara pasti menurut

6 Sjaifurrachman dan Habib Adje., Aspek Pertanggungjawaban Notaris Dalam Pembuatan Akta, Mandan Maju Bandung, 2011, hal. 66. 
hukum berdasarkan pembuktian yang diajukan. Dengan pembuktian, diharapkan dapat dicapai kebenaran menurut hukum serta dapat menjamin perlindungan terhadap hak-hak para pihak yang berperkara, secara seimbang.

Suatu peristiwa yang menimbulkan sesuatu hak, harus dibuktikan oleh yang menuntut hak tersebut, sedangkan peristiwa yang, menghapuskan hak maka harus dibuktikan oleh pihak yang menyangkal hal tersebut. Dengan sendirinya apabila tidak ada bukti-bukti yang diajukan atau tidak cukup diajukan bukti di persidangan, maka tuntutan hak atau gugatan akan di tolak atau tidak dikabulkan. Jadi, peranan notaris dalam hal ini adalah memberikan pelayanan kepada masyarakat, untuk menciptakan suatu alat bukti otentik yang mempunyai kekuatan pembuktian sempurna, membebaskan atau menyadarkan anggota masyarakat dari penipuan atau itikad tidak baik dari orangorang tertentu dan untuk menjamin hak dan kewajiban para pihak yang berkepentingan. Dengan demikian, antara notaris dan para pihak yang membutuhkan jasa notaris harus memiliki integritas, dan moratitas yang tinggi demi terwujudnya perlindungan dan kepastian hukum.

Dalam suatu proses perkara perdata, salah satu tugas hakim adalah untuk menyelidiki apakah suatu hubungan hukum yang menjadi dasar gugatan benar-benar ada atau tidak. Adanya hubungan hukum inilah yang harus terbukti apabila penggugat menginginkan kemenangan dalam suatu perkara. Apabila penggugat tidak berhasil untuk membuktikan dalildalilnya yank menjadi dasar gugatannya akan ditolak, sedangkan apabila, berhasil, gugatannya akan dikabulkan. Pembuktian mengenai suatu peristiwa, mengenai adanya suatu hubungan holden adalah suatu cara untuk menyakinkan hakim akan kebenaran dalil-dalil yang menjadi dasar gugatan, atau dalil-dalil yang telah dikemukakan oleh pihak lawan. Di dalam menjatuhkan beban pembuktian, hakim harus bertindak arif dan bijaksana, serta harus bersikap adil dan tidak memihak.

Setelah berlakunya UndangUndang No.30 Tahun 2004 tentang Jabatan Notaris, dalam sumpah Jabatan Notaris menyatakan bahwa, notaris berjanji dibawah sumpah untuk merahasiakan akta dan keterangan yang diperoleh. Pasal 16 ayat (1) huruf e, juga menyatakan bahwa dalam menjalankan jabatannya, notaris berkewajiban merahasiakan segala sesuatu mengenai akta yang dibuatnya dan segala keterangan yang diperolehnya guna pembuatan akta sesuai dengan keterangan sumpah/janji jabatan, kecuali UndangUndang menentukan lain.

Sumpah Jabatan Notaris dalam Pasal 4 dan kewajiban notaris dalam Pasal 16 ayat (1) huruf e Undang-Undang Jabatan Notaris, mewajibkan notaris untuk tidak berbicara, sekalipun di muka pengadilan, artinya tidak diperbolehkan untuk memberikan kesaksian mengenai apa yang dimuat dalam aktanya. Notaris tidak hanya berhak untuk bicara, akan tetapi mempunyai kewajiban untuk tidak bicara. Kewajiban ini mengesampingkan kewajiban umum untuk memberikan kesaksian sebagaimana yang dimaksud dalam Pasal 1909 KUHPerdata. Notaris adalah jabatan kepercayaan, dan untuk kepentingan masyarakat, dan oleh karena itu seseorang bersedia mempercayakan sesuatu kepadanya. Sebagai seorang yang dipercayakan, notaris berkewajiban untuk merahasiakan semua apa yang diberitahukan kepadanya dalarn jabatannya sebagai notaris, sekalipun ada sebagian tidak dicantumkan dalam akta.

Pasal 322 ayat (1) KUHP menyatakan : Barang siapa dengan sengaja dengan rahasia yang ia wajib menyimpannya oleh karena jabatan atau pekerjaannya, baik sekarang maupun yang dahulu, dipidana dengan pidana penjara selama-lamanya 9 (sembilan) bulan atau denda, sebanyak banyaknya Rp. 600,- (enam ratus rupiah). 
Sebuah akta notaris yang dipersoalkan di depan sidang pengadilan dalam perkara perdata dengan akta yang dibuat oleh notaris, lebih tepat jika menghadirkan seorang notaris yang membuat akta tersebut sebagai saksi ahli. Kehadiran notaris yang membuat akta yang dijadikan alat bukti dalam suatu perkara bukan sebagai saksi biasa melainkan sebagai saksi ahli yang akan menerangkan tentang apa yang saksi ketahui menurut keahlian saksi, berkaitan dengan prosedur baku terbitnya sebuah akta notaris.

Menurut peraturan perundangundangan, saksi ahli dikenal dengan istilah keterangan ahli. Sesuai dengan Pasal 186 KUHAP yang menyatakan bahwa keterangan ahli adalah apa yang seorang ahli menyatakan di sidang pengadilan. Penjelasan Pasal tersebut menjelaskan keterangan ahli ini dapat diberikan pada waktu pemeriksaan oleh penyidik atau penuntut umum yang dituangkan dalam satu bentuk laporan dan dibuat dengan mengikat sumpah di waktu seorang notaris menerima jabatan atau pekerjaan. Setiap orang menurut hukum acara pidana dapat di angkat sebagai saksi ahli, yaitu mempunyai pengetahuan dan pengalaman soal tersebut. ${ }^{7}$ Seorang notaris adalah pejabat yang berwenang menurut ketentuan peraturan perundang-undangan untuk membuat suatu akta yang mencatat segala sesuatu yang disaksikan dan dimintakan untuk dapat dimuat di dalamnya oleh para pihak yang berkepentingan, sehingga kesaksian notaris tentang apa yang dilihat dan apa yang disaksikan oleh notaris dituangkan dalam aktatersebut. Jadi seorang notaris sebenarnya tidak perlu lagi di panggil sebagai saksi dalam suatu persidangan untuk menerangkan apa yang disaksikan dan apa yang disampaikan kepadanya pada saat pembuatan akta yang bersangkutan.

7 Djoko Prakoso, Alat Bukti dan Kekuatan Pembuktian di dalam Proses Pidana, Yogyakarta, Liberty, 1988, hal. 82
Seorang notaris yang dijadikan sebagai saksi dalam suatu perkara, harus mendapat persetujuan dari Majelis Pengawas Daerah.

Sebagaimana diketahui bahwa terhadap notaries diadakan pengawasan yang dilakukan Majelis Pengawas Notaris. ${ }^{8}$ Dalam Pasal 66 ayat (1) Undang-Undang Jabatan Notaris, menyatakan bahwa untuk kepentingan proses peradilan, penyidik, penuntut umum, maupun hakim dengan persetujuan Majelis Pengawas Daerah berwenang:

a) Mengambil fotokopi Minuta Akta dan atau Surat-Surat yang dilekatkan pada Minuta Akta, atau Protokol Notaris dalam penyimpanan notaris;

b) Memanggil notaris untuk hadir dalam pemeriksaan yang berkaitan dengan akta yang dibuatnya atau Protokol Notaris yang berada dalam penyimpanan notaris.

Sehubungan dengan dipanggilnya seorang notaris sebagai saksi di depan persidangan baik dalam perkara perdata maupun perkara pidana terutama kaitannya dengan akta yang dibuatnya, apakah notaris dalam hal ini dapat menuntut diberlakukannya ketentuan yang dimaksud dalam Pasal 50 KUHP, yang menetapkan bahwa barang siapa melakukan perbuatan untuk melaksanakan ketentuan Undang-Undang, tidak dipidana. Maksudnya adalah siapapun yang karena menjalankan suatu peraturan perundangundangan tidak dapat atau tidak boleh di hukum. Permasalahan tersebut, tergantung dari apakah hak ingkar yang diberikan kepadanya oleh Undang-Undang hanya merupakan suatu hak ataukah hanya merupakan kewajiban dan apakah dalam hal ini terdapat suatu kepentingan yang lebih tinggi atau tidak. Berkaitan dengan hal tersebut, maka terdapat tiga kewajiban

8 Petri.A-R-, Perlindungan Hukum Terhadap Notaris (Indikator Tugas-Tugas Jabatan Notaris yang Berimplikasikan Perbuatan Pidana), PT. Sofrnedia, Jakarta, 2011, hal, 84. 
bagi seseorang yang dipanggil sebagai saksi antara lain :

1. Kewajiban untuk menghadap, artinya jika seseorang dipanggil sebagai saksi maka mereka harus menerima dan memenuhi panggilan tersebut sepanjang hal ini tidak merupakan suatu pengecualian dan bahkan jika mereka menolak tanpa alasan yang sah menurut hukum, maka dapat dikenakan sanksi.

2. Kewajiban untuk bersumpah, artinya pada dasarnya semua orang sebelum memberikan keterangan dimuka pengadilan harus di sumpah terlebih dahulu.

3. Kewajiban untuk memberikan keterangan.

Jadi, apabila hak ingkar ini hanya merupakan hak, maka dapatlah seorang notaries menuntut diberlakukannya ketentuan yang dimaksud dalam Pasal. 50 KUHP. Akan tetapi, oleh karena hak ingkar diberikan oleh Undang-Undang bagi notaris merupakan kewajiban dan berdasarkan sumpah rahasia jabatan yang tertuang dalam Pasal 4, serta ketentuan yang terdapat dalam Pasal 54 Undang-Undang Jabatan Notaris, maka tidak ada kewajiban bagi notaris untuk memberikan kesaksian, sekalipun di depan pengadilan. Dengan demikian, penuntutan pemberlakuan dalamPasal 50 KUHP tidak mempunyai dasar hukum yang kuat, kecuali dalam hal adanya kepentingan yang lebih tinggi.

\section{Peran Notaris Dalam Memberikan Keterangan Dalam Proses Peradilan Pidana Dikaitkan dengan Rahasia Jabatannya}

Ruang lingkup pelaksanaan tugas jabatan notaris yaitu dalam ruang lingkup hukum pembuktian, hal ini karma tugas dan kewenangan notaris yaitu membuat alat bukti yang diinginkan oleh para pihak dalam hal tindakan hukum tertentu. Keberadaan alat bukti tersebut dalam ruang lingkup atau tataran hukum perdata. Karena pekerjaan notaris membuat akta tersebut atas permintaan dari penghadap, tanpa adanya permintaan dari para penghadap, notaris tidak akan membuat suatu apapun. Notaris membuat akta berdasarkan alat bukti atau keterangan/pernyataan para pihak yang dinyatakan atau diterangkan atau diperlihatkan kepada atau di hadapan notaris, dan selanjutnya notaris membingkainya secara lahiriah, formil dan materil dalam bentuk akta notaris, dengan tetap berpijak pada aturan hukum atau tata cara atau prosedur pembuatan akta dan aturan hukum yang berkaitan dengan tindakan hukum yang bersangkutan yang dituangkan dalam akta.

Peran notaris dalam hal ini juga untuk memberikan nasehat hukum yang sesuai dengan permasalahan yang ada sebagaimana yang diwajibkan oleh pasal 15 ayat (2) huruf e. UUJN. Apapun nasehat hukum yang diberikan kepada para pihak dan kemudian dituangkan ke dalam akta yang bersangkutan tetap sebagai keinginan atau keterangan para pihak yang bersangkutan, tidak dan bukan sebagai keteranganatau pemyataan notaris. Dalam praktik notaris ditemukan kenyataan, jika ada akta notaris dipermasalahkan oleh para pihak atau pihak lainnya, maka sering pula notaris ditarik sebagai pihak yang turut serta melakukan atau membantu melakukan suatu tindak pidana, yaitu membuat atau memberikan keterangan palsu ke dalam akta notaris. Hal ini pun menimbulkan kerancuan, apakah mungkin notaris secara sengaja (culpa) atau khilaf (alga) bersama-sama para penghadap/pihak untuk membuat akta yang diniatkan sejak awal untuk melakukan suatu tindak pidana?

Dalam kaitan ini tidak berarti notaris steril atau bersih dari hukum atau tidak dapat dihukum atau kebal terhadap hukum. Notaris bisa saja dihukum pidana jika dapat dibuktikan di pengadilan bahwa secara sengaja atau tidak disengaja notaris bersama-sama dengan para pihak/penghadap untuk membuat akta 
dengan maksud dan tujuan untuk menguntungkan pihak atau penghadap tertentu saja atau merugikan penghadap yang lain. Jika hal ini terbukti dalam persidangan, maka notaris tersebut wajib dihukum. Oleh karena itu, hanya Notaris yang tidakwaras dalammenjalankan togas jabatannya, ketika membuat akta untuk kepentingan pihak tertentu dengan maksud untuk merugikan pihak tertentu atau untak melakukan suatu tindakan yang melanggar bukum. $^{9}$

Dalam rangka proses pembuktian terhadap indikasi perbuatan pidana dalam akta otentik tersebut di atas, maka diperlukan kehadiran notaris dalam pemeriksaan perkara pidana mulai dari tingkat penyidikan di Kepolisian, penuntutan olehKejaksaan hingga proses pembuktian dalam sidang di Pengadilan. Perlunya kehadiran notaris dalam pemeriksaan perkara pidana berkaitan dengan akta yang dibuat dan berindikasi perbuatan pidana sangat ditentukan oleh aspek formal dan materiil akta notaris itu sendiri. Dalam kasus yang sering melibatkan notaris sebagai tersangka berdasarkan bukti awal pada laporan polisi yang terkait dengan akta notaris yang dibuatnya dinilai berindikasi perbuatan pidana, sehingga notaris perlu dipanggil untuk menjelaskan proses terjadinya akta tersebut, dan alas bukti yang dijadikan dasar pembuatan akta tersebut. Untuk keperluan pemanggilan notaris berdasarkan pasal 66 ayat 1 buruf b. Kepolisian harus mendapatkan ijin terlebih dahulu dari Majelis Pengawas Daerah. Atas dasar permohonan ijin dari Kepolisian tersebut maka Majelis PengawasDaerah (MPD) mengadakan sidang majelis untuk memeriksa notaris sehubungan dengan perlu atau tidaknya notaris memberikan keterangan pada pemeriksaan perkara

\footnotetext{
${ }^{9}$ Habib Adjie, Hokum Notaris Indonesia, (Tafsir Tematik Terhadap UU No 30 Tahun 2004 Tentang Jabatan Notaris), PT. Refika Aditama, Bandung, 2008, hal24
}

pidana di Kepolisian sebagaimana Surat permohonan ijin pemeriksaan notaris yang diterima oleh Majelis Pengawas Daerah. Berdasarkan hasil sidang majelis pengawas maka Majelis Pengawas Daerah memberikan ijin untuk melakukan penyidikan atau meminta keterangan terhadap notaris tersebut.

Ketentuan Pasal 66 UUJN tersebut bersifat imperatif atau perintah artinya jika Kepolisian, Kejaksaan atau Hakim menyepelekan ketentuan Pasal 66 UUJN, maka terhadap Kepolisian, Kejaksaan atau Hakim dapat dikategorikan sebagai pelanggaran terhadap undang-undang, maka jika hal ini terjadi, kita dapat melaporkan Kepolisian, Kejaksaan dan Hakim kepada atasannya masing-masing, dan di sisi yang lain, perkara yang disidik atau diperiksa tersebut dapat dikategorikan carat hukum (dari segi Hukum Acara Pidana) yang tidak dapat dilanjutkan (ditunda untuk sementara) sampai ketentuan Pasal 66 UUJN dipenuhi. Ada juga Notaris yang dipanggil oleh Kepolisian, Kejaksaan atau Hakim langsung datang menghadap kepada intansi yang memanggilnya, tanpa diperiksa terlebih dahulu oleh Majelis Pengawas Daerah.

Faktor yang menyebabkan notaris diperlukan kehadirannya dalam pemeriksaan perkara pidana adalah :

1. Apabila akta yang dibuat oleh notaris menimbulkan kerugian yang diderita para pihak maupun pihak lain dan berdasarkan bukti awal bahwa notaris patut diduga turut serta melakukan atau membantu melakukan suatu tindak pidana, berkaitan dengan kewenangan notaris berdasarkan pasal 15 UUJN yaitu membuat akta otentik dengan adanya unsur-unsur tindak pidana seperti
a. 55 KUHP yaitu turut serta melakukan tindak pidana.
b. 231 KUHP yaitu membantu pelaku dalam melakukan kejahatan.


c. 263 KUHP yaitu membuat Surat palsu.

d. 266 KUHP yaitu memberikan keterangan palsu dalam akta otentik.

e. 372 KUHP yaitu penggelapan.

f. 378 KUHP yaitu penipuan.

g. 385 KUHP yaitu menjual, menukarkan atau membebani dengan credietverband (sekarang Hak Tanggungan) atas tanah yang belum bersertifikat.

2. Untuk mendapatkan keterangan dari notaris baik secara formil maupun materiil berkaitan dengan akta yang dibuatnya berdasarkan laporan para pihak atau pihaklain yang dirugikan atas akta tersebut (aktanya berindikasi adanya perbuatan pidana), sehingga perlu dilakukan pemeriksaan yang obyektif oleh penyidik, karena Kepolisian wajib menerima laporan ataupun pengaduan masyarakat dan menindak lanjuti dengan pemanggilan guna diminta keterangannya karena fangsi penyidik Kepolisian adalah membuat terang suatu tindak pidana. Terhadap kehadiran notaris dalam pemeriksaan perkara pidana khususnya penyidikan di Kepolisian.

3. Merupakan kewajiban setiap warga/anggota masyarakat untuk menghadiri pemeriksaan pidana sebagai saksi, saksi ahli atau juru bahasa berdasarkan pasal 224KUHP yang menyatakan bahwa : "barang siapa dipanggil sebagai saksi, saksi ahli atau juru bahasa menurut undang-undang dengan sengaja tidak memenuhi suatu kewajiban yang menurut undangundang selaku demikian harus dipenuhinya, diancam:

1) Dalam perkara pidana, dengan pidana penjara paling lama sembilan bulan;

2) Dalam perkara lain, dengan pidana penjara paling lama enam bulan.
Ketentuan ini berlaku juga bagi notaris sebagai pejabat umum namun demikian berdasarkan pasal 66 UUJN bahwa pemanggilan notaris dalam pemeriksaan perkara pidana harus mendapat ijin terlebih dahulu dari Majelis Pengawas Daerah bagi Kota atau Kabupaten yang mempunyai Majelis Pengawas Daerah, atau Majelis Pengawas Wilayah bagi Kota/Kabupaten yang belum mempunyai Majelis Pengawas Daerah.

Meskipun notaris mempunyai Immunitas hukum yang diberikan undang-undang berupa kewajiban untuk menolak memberikan keterangan yang menyangkut rahasia jabatannya, dan Immunitas tersebut diwujudkan dengan adanya hak ingkar atau mengundurkan diri sebagai saksi sepanjang menyangkut keterangan-keterangan yang sifatnya rahasia jabatan. Sebagai pejabat umum yang menjalankan pelayanan publik dibidang pelayanan jasa hukum, maka terhadap kesalahan notaris perlu dibedakan antara kesalahan yang bersifat pribadi (faute personelle atau personal fault) dankesalahan didalam menjalankan tugas (faute de serive atau in service fault). ${ }^{10}$ Seperti dalam perkara perdata maka dalam perkara pidanapun diatur mengenai adanya pengecualianpengecualian bagi orang atau pejabat yang dapat menolak atau mengundurkan diri menjadi saksi yaitu sebagaimana yang tertera dan tereantumdalamPasal 170 KUHAP yaitu :

(1) Mereka yang karena pekerjaan, harkat martabat atau

10 Paulus Efendi Lotulung, Perlindungan Hukum Bagi Notaris Selaku Pejabat Umum Dalam Menjalankan Tugasnya,Media Notariat, Ikatan Notaris Indonesia, Edisi April, 2002, hal. 3. 
jabatannya diwajibkan menyimpan rahasia, dapat minta dibebaskan dari kewajiban untuk memberi keterangan sebagat saksi, yaitu tentang hal yang dipercayakan kepada mereka.

(2) Hakim menentukan sah atau tidaknya segala alasan untuk permintaan tersebut.

4. Berdasarkan pasal 65 UUJN bahwa notaris bertanggung jawab atas setiap akta yang dibuatnya meskipun protokol notaris telah diserahkan kepada penyimpan protokol notaris. Artinya tanggung jawab notaris tidak berakhir meskipun notaris telah pension/purna tugas, sehingga setiap saat dapat dimintai pertanggungjawabannya atas akta yang dibuat.

5. Berdasarkan pasal 184 KUHAP (Kitab Undang-undang Hukum Acara Pidana) Dalam perkara pidana, alat bukti keterangan saksi merupakan alat bukti yang paling utama disamping alat bukti yang lainnya seperti keterangan ahli, surat (bukti-bukti tertulis), petunjuk dan keterangan terdakwa. Tidak ada perkara pidana yang luput dari pembuktian alat bukti keterangan saksi. Hampir semua pembuktian perkara pidana, selalu bersandar kepada pemeriksaan keterangansaksi. Sekurang-kurangnya di samping pembuktian dengan alat bukti yang lain seperti persangkaan atau bukti tertulis bahkan pengakuan dari terdakwa sekalipun, masih selalu diperlukan pembuktian dengan alat bukti keterangan saksi. ${ }^{11}$ Oleh karena itu untuk mendapatkan hasil pemeriksaan yang obyektif dan sempuma penyidik sangat memeriukan keterangan saksi, meskipun yang menjadi saksi seorang notaris.

11 M. Yahya Harahap, Pembahasan Permasalahan dan Penerapan KUHAP, Penyidikan dan Penuntutan, edisi ke-dua, Sinar Grafika, 2002, hal. 265.
Telah menjadi alas hukum publik bahwa seorang pejabat umum, sebelum menjalankan jabatannya dengan sah harus terlebih dahulu mengangkat sumpah (di ambil sumpahnya). Selama hal tersebut belum dilakukan, maka jabatan itu tidak boleh atau tidak dapat dijalankan dengan sah. Notaris dalam menjalankan tugas jabatannya harus berdasarkan wewenang yang telah ada pada jabatan. Notaris itu sendiri. ${ }^{12}$ Sesuai dengan isi dari Pasal 4 ayat (1) Undang-Undang Jabatan Notaris yang berbunyi, bahwa notaris sebelum menjalankan jabatannya, wajib mengucapkan sumpah/ janji menurut agamanya di hadapan Menteri atau Pejabat yang ditunjuk. Sedangkan pada ayat (2) menyatakan : Saya bersumpah/berjanji : Bahwa saya akan patch dan setia kepada negara Republik Indonesia, Pancasila, dan Undang-Undang Dasar Republik Indonesia Tahun 1945, Undang-Undang tentang Jabatan Notaris, serta peraturan perundang-undangan lainnya. Bahwa saya akan menjalankan jabatan saya dengan amanah, jujur, seksama, mandiri, dan tidak berpihak. Bahwa saya akanmenjaga sikap, tingkah laku saya, dan akan menjalankan kewajiban saya sesuai dengan Kode Etik Profesi, kehormatan martabat, dan tanggung jawab saya sebagai notaris. Bahwa saya akan merahasiakan isi akta dan keterangan yang diperoleh dalam pelaksanaan jabatan saya. Bahwa saya untuk dapat diangkat dalam jabatan ini, baik secara langsung, dengan nama atau dalih apapun, tidak pernah dan tidak akan memberikan atau menjanjikan sesuatu kepada siapapun. Berdasarkan ketentuan yang di atur dalam Pasal 4 tersebut menyatakan bahwa notaris yang diangkat itu sebelum mengangkat sumpah tidak diperkenankan untuk melakukan suatu pekerjaan yang termasuk dalam bidang Jabatan Notaris. Sebelum diadakan sumpah

12 Habib Adjie., Bernas-Bernas Pemikiran di Bidang Notaris dan PPAT, Penerbit CV. Mandar Maju, Bandung, 2012, bal- 13. 
jabatan bagi seorang notaris, notaris tidak berhak untuk membuat akta otentik. Apabila seorang notaris melanggar ketentuan tersebut, maka selain dikenakan sanksi, akta yang dibuat oleh notaris tersebut tidak akan mempunyai sifat otentik melainkan hanya berlaku sebagai akta di bawah tangan, apabila di tandatangani oleh para pihak. Dalam sumpah Jabatan Notaris menyatakan, notaris berjanji di bawah sumpah untuk merahasiakan isi akta dan keterangan yang diperolehnya. Pasal 16 ayat (1) huruf e juga menyatakan bahwa dalam menjalankan jabatannya, notaris berkewajiban merahasiakan akta yang dibuatnya dan segala keterangan yang diperoleh guna pembuatan akta sesuai dengan sumpah/janji jabatan, kecuali UndangUndang menentukan lain. Di dalam penjelasan Pasal tersebut dikatakan bahwa kewajiban untuk merahasiakan segala sesuatu yang berhubungan dengan akta dan surat-surat lainnya adalah untuk melindungi kepentingan semua pihak yang terkait dengan akta tersebut. Pasal 322 ayat (1) KUHP juga menyatakan bahwa, barangsiapa dengan sengaja membuka rahasia yang ia wajib menyimpannya oleh karena jabatan atau pekerjaannya, baik sekarang maupun yang dahulu, dipidana dengan pidana penjara selama-lamanya 9 (sembilan) bulan atau denda sebanyakbanyaknya Rp. 600,- (enam ratus rupiah). Berdasarkan kedua Pasal yang telah dijabarkan diatas, maka sudah jelas bahwa notaris harus merahasiakan yang berhubungan dengan jabatannya Notaris berkewajiban untuk merahasiakan isi aktanya, bahkan notaris wajib merahasiakan semua keterangan mulai dari persiapan pembuatan akta hingga selesainya pembuatan suatu akta. Mereka apabila dijadikan saksi dalam perkara, dapat menggunakan haknya untuk mengundurkan diri sebagai saksi.

Apabila seorang notaris membuka rahasia jabatan yang di amanatkan padanya, maka kepadanya diancam dengan pidana berdasarkan:

Pasal 322 Kitab Undang-Undang Hukum Pidana :

a) Barang siapa dengan sengaja membuka rahasia yang wajib disimpannya karenajabatan atau pencariannya, baik yang sekarang, maupun yang dahulu, diancamdengan pidana penjara paling lama 9 (sembilan) bulan atau denda paling banyakRp. 600,- (enam ratus).

b) Jika kejahatan dilakukan terhadap seorang tertentu, maka perbuatan itu hanya dapat dituntut atas pengaduan orang itu.

Apabila akibat dibukanya rahasia seseorang oleh notaris atau karyawan notaris, sehingga menjadi diketahui oleh masyarakat dan mengakibatkan kerugian bagi orang yang bersangkutan, maka notaris tersebut dapat digugat secara perdata berdasarkan: Pasal 1365 Kitab Undang-Undang Hukum Perdata menyatakan bahwa setiap perbuatan melanggar hukum, yang membawa kerugian pada orang lain, mewajibkan orang yang karena salahnya menerbitkan kerugian itu, mengganti kerugian tersebut.

Merahasiakan segala sesuatu mengenai akta yang dibuat dan segala keterangan yang diperoleh guna pernbuatan akta merupakan salah satu kewajiban notaris. Pelanggaran terhadap kewajiban menjaga kerahasiaan jabatan dapat mengakibatkan notaris dikenakan sanksi oleh Majelis Pengawas Notaris, hal ini sesuai dengan ketentuan Pasal 85 Undang-Undang Jabatan Notaris antara lain :
a) Teguran lisan;
b) Teguran tertulis;
c) Pemberhentian sementara;
d) Pemberhentian dengan hormat;
e) Pemberhentian dengan tidak hormat oleh Menteri atas usul Majelis Pengawas Pusat.




\section{D.PENUTUP}

\section{Kesimpulan}

1. Dalam hal memberikan kesaksian, seorang notaris tidak dapat mengungkapkan akta yang dibuatnya balk sebagian maupun keseluruhannya kepada pihak lain, hal ini sesuai dengan Pasal 54 Undang-Undang Jabatan Notaris karena sebagai seorang kepercayaan, notaris berkewajiban untuk merahasiakan semua hal yang diberitahukan kepadanya dalam jabatannya sebagai notaris, sekalipun ada sebagian yang tidak dicantumkan dalam akta, dan telah dianggap mewakili diri notaris dalam suatu persidangan sehingga akta yang, dibuat oleh atau di hadapan notaris merupakan suatu alat bukti yang mempunyai kekuatan pembuktian yang sempurna.

2. Seorang notaris harus mendapatkan persetujuan terlebih dahulu dari Majelis Pengawas Daerah dan harus jelas kedudukannya dalam suatu perkara sebagai saksi atau tersangka terhadap akta yang dibuatnya, serta harus jelas keterangan apa yang diperlukan oleh penyidik, penuntut umum, maupun hakim, namun notaris dibatasi dengan rahasia jabatan sebagaimana yang tercantum dalam sumpah jabatan notaris dalam Pasal 4 dan kewajiban notaris dalam Pasal 16 ayat (1) huruf e Undang-Undang Jabatan Notaris. Dalam penjelasan Pasal tersebut dikatakan bahwa kewajiban untuk merahasiakan segala sesuatu yang berhubungan dengan akta dan surat-surat lainnya adalah untuk melindungi kepentingan semua pihak yang terkait dengan akta tersebut. Notaris tidak hanya berhak untuk bicara, akantetapi mempunyai kewajiban untuk tidak bicara. Kewajiban tersebut mengesampingkan kewajiban umum yang tercantum dalam, Pasal 1909 ayat (1) KUHPerdata karena dalam profesi notaris dikenal adanya istilah mengenai hak ingkar yaitu merupakan konsekuensi dari adanya kewajiban merahasiakan sesuatu yang diketahuinya.

\section{Saran}

1. Sebaiknya dalam memberikan kesaksian terhadap suatu perkara yang melibatkan notaris menjadi saksi di muka persidangan, seorang, notaris dapat tetap memegang teguh apa, yang tercantum dalam sumpah jabatannya. Dan untuk itu diperlukan suatu jaminan kepastian hukum yang diatur lebih terperinci lagi dalam suatu peraturan perundang-undangan bagi notaris, apabila ia menjadi seorang saksi dalam persidangan agar tetap dapat terlindungi dari segala bentuk sanksi yang diterapkan dalam suatu peraturan perundang-undangan tertentu.

2. Hendaknya bagi semua pihak baik penyidik, penuntut umum, maupun hakim dapat menghormati, menjunjung tinggi sumpah jabatan, rahasia jabatan, dan hak ingkar yang dimiliki oleh notaris, dan seyogyanya dapat bekerja sama dengan baik dan tetap memegang teguh tentang adanya Kode Etik di setiap profesi tak terkecuali untuk profesi notaris sekalipun. Dengan adanya upaya-upaya tersebut, diharapkan sebagai salah satu upaya untuk menegakkan hukum dan diharapkan juga berdampak positif bagi penegakkan hukum itu sendiri.

\section{DAFTAR PUSTAKA}

Bambang Waluyo, Penelitian Hukum Dalam Praktek, Sinar Grafika, Jakarta, 1996.

Daryanto,S.S., Kamus Bahasa Indonesia Lengkap, Penerbit Apollo, Surabaya, 1997.

Djoko Prakoso, Alat Bukti dan Kekuatan Pembuktian di dalam Proses Pidana, Yogyakarta, Liberty, 1988. 
Habib Adjie, Bernas-Bernas Pemikiran di Bidang Notaris dan PPAT, Penerbut CV. Mandar Maju, Bandung, 2012.

Habib Adjie., Hukum Notaris Indonesia, (Tafsir Tematik Terhadap UU No 30 Tahun 2004 Tentang Jabatan Notaris), PT. Refika aditama, Surabaya, 2008.

Hadjon, Philipus M., dkk., Pengantar Hukum Administrasi Indonesia (Introduction to The Indonesia Administrative Law), Yogyakarta Gadjah Mada University Press, 2002.

Husni Thamrin., Pembuatan Akata Pertanahan Oleh Notaris, Laksabang Pressindo, Yogyakarta, 2011.

Joko Sukisno, Mengkritisi Undang-Undang No. 30 Tahun 2004 Tentang Jabatan Notaris, Yogyakarta : Simposium Sosialisasi dan diskusi UU No. 30 Tahun 2004, 2005.

Komar Andasasmita,Notaris Selayang Pandang, Bandung, Alumni, 1983.

Notaris Berkomunikasi, Bandung : Alumni, 1984.

Liliana Tedjosaputro, Etika Profesi Notaris (Dalam Penegakan Hukum Pidana), Yogyakarta, Biograf Publishing, 1995.

Lumban Tobing. G ,S, Peraturan Jabatan Notaris, cet. 3, Jakarta, Erlangga, 1983.

. , Peraturan Jabatan Notaris, Jakarta : Erlangga, 1996.

Majelis Pengawas Pusat Notaris Departemen Hukum dan HAM Republik Indonesia, Pemberian atau Penolakan Persetujuan Pemanggilan Notaris, Renvoi (Oktober 2005).

Mahja Djuhad, Undang-Undang, Nomor 30 Tahun 2004 tentang Jabatan Notaris, Durat Bahagia, Jakarta, 2005.

Paulus Efendi Lotulung, Perlindungan Hukum Bagi Notaris Selaku Pejabat Umum Dalam Menjalankan Tugasnya,Media Notariat, Ikatan Notaris Indonesia, Edisi April, 2002.

Putri. A.R., Perlindungan Hukum Terhadap Notaris (Indikator Tugas-Tugas Jabatan Notaris yang Berimplikasikan Perbuatan Pidana), PT. Sofmedia, Jakarta, 2011.
Retnowulan Sutantio dan Iskandar Oeripkartawinata, Hukum Acara Perdata dalamTeori dan Praktek, Bandung, CV. Mandar Maju, 2005.

Rinduan Syahrani, Hukum Acara Perdata dalam Lingkungan Peradilan Umum, Jakarta, Pustaka Kartini, 1988.

Soekanto, Soerjono dan Sri Mamudji., Penelitian Hukum NormatifSuatu Tinjauan Singkat, Jakarta : CV. Rajawali, 1985.

Sunaryati Hartono, Penelitian Hukum Di Indonesia Pada akhir Abad Ke-20, Alumni, Bandung, 1994.

Sjaifurrachman dan Habib Adjie., Apsek Pertanggungjawaban Notaris DalamPembuatan Akta, Penerbit Mandar Maju Bandung, 2011.

\section{Peraturan perundang-undangan :}

Undang-Undang No. 30 Tahun 2004 tentang Jabatan Notaris.

Kitab Undang-Undang Hukum Perdata.

Kitab Undang-Undang Hukum Pidana.

Kitab Undang-Undang Hukum Acara Pidana. 